\title{
The Role of Ombudsman to Encourage The Citizens' Participation in Public Service Supervision through Ombudsman Network
}

\author{
Aulia Sholichah Iman Nur Chotimah and Idrus Affandi \\ Universitas Pendidikan Indonesia \\ Bandung, Indonesia \\ aulia_sinc@yahoo.com
}

\begin{abstract}
Citizens certainly have rights and obligations; one form of citizens' rights is obtaining good public services. In public service, most of the citizens do not understand that there is a right of the citizens to complain or to give feedback about the service received if the implementer and the organizer do the service standard wrong. Ombudsman institution as a state institution which has the duty to oversee the implementation of public services should be better known to the public. In fact, Ombudsman institution is still unknown to the citizens specifically in Central Java because the ombudsman institution is only located at the center of Central Java and it has its representative only in the province. Even though in the article 2 of the Law, it has been mentioned that the Ombudsman may form Ombudsman representatives in the province and / or in the district and city. However, due to the limitations of the Ombudsman, it only comes to the province representatives. It makes the supervision of public services limited and requires citizen's participation to assist in the implementation of public service supervision. This study uses qualitative method. This research deeply explores about how the Ombudsman's efforts of Central Java Representative to encourage citizens' participation in the public services supervision. The result of this research is about the Ombudsman Network which consists of various backgrounds as the tool of the Central Java Ombudsman representative to encourage public participation in public service supervision.
\end{abstract}

Keywords - the role of ombudsman; the citizens participation; public service supervision; ombudsman network

\section{INTRODUCTION}

Central Java Ombudsman representative is considered as newly formed representative because it was established in October 2012, previously it was under the authority of The Special Region of Yogyakarta Ombudsman representative. Each Ombudsman's representative in the province has an internal policy in order to encourage public participation in the public service supervision. The Central Java Ombudsman representative has an internal policy to encourage public participation in the public services supervision in Central Java through various programs. According to the report of Central Java Ombudsman Representative, citizens' reports on public services to the Regional Ombudsman of Central Java in 2017 increased from 141 reports in 2016 to 234 maladministration reports from January to the first week of December 2017. Increased Maladministration reports show the existence of increased external supervision. The biggest report came from citizens in Semarang which is the capital city of Central Java. In the contrary, some remote areas in Central Java have not got the equal information and the citizens still do not participate well in the supervision of public services, it can be seen from the compliance level of several regions in Central Java which are still in the yellow zone and even decreased, namely the level of compliance of public services in Banyumas, Batang, Kudus, Temanggung, Salatiga, and Surakarta. Ideally all citizens of Central Java have to participate actively in the supervision of public services. That is the way to create public service improvement in Central Java. Therefore, it is necessary to encourage the citizens' participation to supervise the public service up to the smallest scope in the region in order to reach all citizens who can participate well in the public services supervision.

This research's position in the study of Civics Education can be seen from the ontology of Civics Education which has two dimensions as stated by Winataputra, namely the object of study and development object [1]. The object of study is the whole aspects of the ideological, instrumental, and praxis of Civics Education that internally and externally supports the curriculum and learning systems of Civics Education inside and outside the schools, as well as the format of socio-cultural movements of the community. The position of this research in the ontology of Civics Education is in the sociocultural domain which belongs to the study and transformation of Civics for the community in general. Sociocultural domains of Civics education are designed for the development of citizens in the community. In fact, Civics as a socio-cultural program in Indonesia still has weaknesses at the program and operational level. It can be seen from the lack of awareness in the practice of law or legalization in the society.

There are three important points of Civics Education goals in the democratic citizens formation; those are smart and good citizens, participative citizen, and responsible citizen [2]. Smart citizens are citizens who understand their rights and obligations as citizens, including their rights and obligations in the public service supervision. Supervision in public services should be a shared responsibility between government and citizens. The 
form of supervision can be done by participating significantly in the supervision of public services. It belongs to the essential components of Civics Education. It is called Civics Skills.

Participation in the public service supervision is included in the objectives of Civics education, this is what the Ombudsman always do, Asmara explains that based on the apparatus or controlled institution that are overseen by Ombudsman, it is found that there is Ombudsman who only oversees government officials or institutions (executive) and there is ombudsman who only supervise the court (judicial) [3]. The Swedish and Finnish Ombudsmen are examples of Ombudsmen overseeing judicial or judicial apparatus or apparatus other than executives. Ombudsmen are the examples of the ombudsmen who only oversee the government apparatus without the authority to oversee the judicial apparatus or institutions. Ombudsman of The Republic of Indonesia which hereinafter referred to the Ombudsman, is a State Institution which has the authority to oversee the Implementation of Public Service either organized by the State and government organizers including those held by State Owned Enterprises, Regional Government Enterprises and State-Owned Legal Entities as well as Private or Private Institutions given the task of providing certain public services which part or all of its funds are sourced from the State budget of revenues and expenditures and / or the regional income and expenditure budget [4]. Asmara in his journal states that citizens' participation in supporting the implementation of Ombudsman's duties and functions is very important. But such participation is impossible if the citizens have not recognized this institution, whether it is related to its position, duties and functions and its benefits to society, nation and state [3]. If public do not know the Ombudsman, it could not be expected that citizens would report the maladministration actions in the public service. Therefore, the second attempt to strengthen the existence of Ombudsman is to conduct socialization efforts to the citizens through various ways, such as through print and electronic media, seminars, workshops, complaint clinics, talk shows, interactive dialogues, public lectures, etc. Socialization can also be done throughout the Ombudsman Complaint Week, public dialogue through mass media, etc. This is in line with what Luthfiana I.I \& Kania, D, stated in their journals that advertising, public relations \& special events, printed materials, special items, personal selling, and social media channels \& types partially have a positive and significant influence on brand awareness [5].

\section{RESEARCH METHODS}

This research uses qualitative methods. Research method is basically a scientific way to get data with a specific purpose and usefulness [6]. According to Furchan (in Prastowo) states research method is a general strategy adopted in the research [7]. Methods of data collection in this study using data collection techniques in the form of observation, interviews and documentation. This research also apply interview to some informants. The first informant is Executive Ombudsman Chairperson Representative of Central Java as someone who knows about citizen participation forms in public service supervision. The second informant is Ombudsman Assistant Representative of Central Java from Participation Community
Division, and Ombudsman Assistant of Central Java from Detection and Report Completion Division. Other informants are citizens who have been trained by Central Java Ombudsman Representative known as "Konco Ombudsman". Subsequent data collection techniques are documentation. The documentation is obtained from many activities which include the citizens' participation in public services supervision in Central Java

\section{RESULTS AND DISCUSSION}

Ombudsman encourages citizens' participation in the public service supervision through the Ombudsman network. The involvement of public in conducting the oversight activities of the public service, either in the form of statements or in the form of activities by giving thoughts, energy, time, and expertise, from their own will and the desire to make a move in the supervision of public services. The Ombudsman Network in Central Java is called "Konco Ombudsman".

The Ombudsman's goal to encourage citizens' participation is to build citizens' understanding of public services and to influence the policy making in improving the public services for the achievement of community welfare. Then, the purpose of Ombudsman networks both individuals and organizational are as follows:

- To form opinions (thoughts) through the mass media that citizens really need public service and welfare;

- To give solutions for the problems faced by the citizens by sending information to the government and the Ombudsman of The Republic of Indonesia;

- To criticize the public policies and services that are not in favor of the community interests;

- To provide moral support to the Ombudsman of the Republic of Indonesia.

In cooperation with the Ombudsman network, Ombudsman applies some indicators to the quality and quantity of network members capabilities in organizing the increase of citizens' participation, not only about the synergy of performance programs of network members who have to know about public services and maladministration information. The quality and quantity of communication and data collection or selection morally strengthen the support of the Ombudsman RI. Consequently, the number of complaints units increased and the level of public confidence in Ombudsman increased.

The roles of the Ombudsman Network in dealing with reports are to open a citizen-based complaint unit or be a reference for other citizens who submit their reports or complaints; to provide assistance to the reporters in submitting their complaints to the Ombudsman after taking other measures that have not been treated equally; Ombudsman network also plays a role to open the public knowledge about Ombudsman and to provide information on public services and maladministration indications.

Another ombudsman's effort to encourage citizens' participation is through dissemination. Dissemination aims to improve new networks through increasing the number of 
followers in Ombudsman social media. So that there is the increase of the publications on maladministration and public services. The method used for dissemination is visiting the participants who will be given dissemination, inviting the participants to the Ombudsman event through social media. Other medias used are internet citizens (blasting activities of Ombudsman RI), announcement boards, short videos, banners and billboards. The second effort is through training for potential trainers, it is a training for ombudsman networks that will be the trainers for other Ombudsman networks or other citizens. The Ombudsman increases the number of trainers, facilitators, companions in the environment of the Ombudsman network. Then, Ombudsman encourage the citizens' participation through regular meetings. Regular meetings are held by the Ombudsman toward the Ombudsman network. Ombudsman meetings are held well-scheduled by each representative, within the level of region. Regional and national meetings involving the entire Ombudsman network to make a commitment, such as making a MoU (institutional MoU is not included).

There are several strategies for maintaining Ombudsman network. Firstly, open internship opportunities in the Ombudsman office both in Ombudsman RI and in Ombudsman Representative. Secondly, prepare accessible official facilities and infrastructure for Ombudsman network. Then, the third strategy is to provide training that were previously done by Ombudsman to Ombudsman network. Lastly, do the Advocacy training.

The research findings are consistent with the theory of Asmara, G. that citizens' participation in supporting the implementation of the duties and functions of Ombudsman is essential [3]. The second attempt to strengthen the existence of the Ombudsman institution is to conduct socialization efforts to the community through various medias, such as print and electronic media, seminars, workshops, complaints clinic, talk shows, interactive dialogues, and public talks.

\section{CONCLUSIONS AND SUGGESTIONS}

\section{A. Conclusion}

Ombudsman encourages citizens' participation in the public services supervision through the Ombudsman network. The objective of the Ombudsman in encouraging citizens' participation are to build citizens' understanding of public services and influence policies in public services improvements to achieve welfare. The ombudsman's efforts to encourage citizens' participation are firstly, through disseminations; secondly, through training for trainers; and thirdly, through regular meetings.

\section{B. Suggestion}

Central Java Ombudsman representatives should encourage the participation of Ombudsman networks to participate actively in the supervision of public administration. They should create more innovative methods in implementing the dissemination and training for the Ombudsman networks. There also should be sustainable activities after the disseminations as well as regular trainings and meetings, which provide opportunities to Ombudsman networks to participate actively in public service supervision related to networking strategies.

\section{REFERENCES}

[1] Winataputra, Udin. Teori Belajar dan Pembelajaran. Jakarta: Universitas Terbuka. 2008.

[2] Wahab and Sapriya. Teori dan Landasan Pendidikan Kewarganegaraan. Bandung: Alfabeta. 2011.

[3] Asmara, G. "Strengthening Ombudsman Institutions of the Republic of Indonesia to Increase Protection of Citizens' Rights in Public Services,' Mediterranean Journal of Social Sciences, vol. 8 (5), 2017, pp. 51-57.

[4] Law Number 37 of 2008 on Ombudsman RI

[5] Luthfiana, I. I., \& Kania, D. "Pengaruh Komunikasi Pemasaran Sosial terhadap Brand Awareness Ombudsman Republik Indonesia,” Journal Communication Spectrum, vol. 4 (1), 2017, pp. 24-42.

[6] Sugiyono. Metode Penelitian Pendidikan Pendekatan Kuantitatif, Kualitatif, dan R\&D. Bandung: Alfabeta. 2013.

[7] Prastowo, Andi. Metode Penelitian dalam Perspektif rancangan Penelitian. Yogyakarta: Ar-Ruzz Media. 2011. 